\title{
EQUITY'S MANHATTAN PROJECT: THE CREATION AND EVOLUTION OF THE MAREVA INJUNCTION
}

\author{
John Stevens ${ }^{*}$
}

Lord Denning was the twentieth century's pre-eminent exponent of the continuing creative potential of equity, ${ }^{1}$ and of the ability of the judiciary to implement wide ranging law reform without the legislative intervention of Parliament. Whilst many of his reforms have fallen by the wayside, ${ }^{2}$ condemned both on the grounds of their dubious historical pedigree and their unsettling practical implications, the Mareva injunction has survived the test of time to become a standard weapon in the armoury of commercial litigation. In Bank Mellat v. Nikpour Donaldson L.J. went so far as to describe the Mareva injunction as one of the two "nuclear weapons" of the law. ${ }^{4}$ Lord Denning himself, writing extra-judicially, has commented that the creation of the Mareva jurisdiction was "the greatest piece of judicial law reform in my time." If the evolution of the Mareva injunction can be compared to the development of the atomic bomb, he was without doubt the Robert Oppenheimer of the law's "Manhattan Project," and the father of the Mareva injunction. The purpose of this article is to chart the creation and evolution of this most enduring contribution of Lord Denning to the English legal system, and to consider what implications this history might have for legal development today.

\footnotetext{
* Lecturer in Law, The University of Birmingham.

${ }^{1}$ See for example: Boyer v. Warbey [1953] 1 Q.B. 234 (privity of estate extended to equitable leases); Solle v. Butcher [1950] 1 K.B. 671 (mistake in equity); Binions v. Evans [1972] Ch. 359 (contractual licence a proprietary right); Eves v. Eves [1975] 1 W.L.R. 1338 ("new model" constructive trusts).

${ }^{2}$ See for example: National Provincial Bank v. Ainsworth [1965] A.C. 1175 (deserted wife's equity); Grant v. Edwards [1986] Ch. 638 ("new model" constructive trust); Ashburn Anstalt v. Arnold [1989] Ch. 1 (contractual licence).

${ }^{3}$ The other being the Anton Piller order see Anton Piller K.G. v. Manufacturing Processes Ltd. [1976] Ch. 55.

${ }^{4}$ [1985] F.S.R. 87 at 92.

5 The Due Process of Law, (Butterworths, 1979) at p.134.
} 


\section{CREATION OF THE MAREVA INJUNCTION}

A Mareva injunction operates so as to restrain a defendant, or a third party holding a defendant's assets, ${ }^{6}$ from disposing of assets ${ }^{7}$ which could otherwise satisfy a judgement which might be awarded against him. Historically the court was thought to possess no jurisdiction in equity to award such an injunction. In Lister v. Stubbs the Court of Appeal held not only that a fiduciary who had taken a bribe was not a constructive trustee of the money received on behalf of his principal, but also that a principal was not entitled to an injunction to restrain his fiduciary from dealing with the investments he had acquired with the bribe money, nor to require him to pay that sum into court on the grounds that he was prima facie a debtor to the principal in respect of the sum he had received. ${ }^{8}$ Cotton L.J. was of the opinion that to grant such an order would introduce a "new and entirely wrong principle." Thus the court would not act to protect the prospective rights of a judgement creditor, even where a prima facie case was extremely strong.

This historic barrier to injunctive relief to prevent the dissipation of assets was consigned to history by Lord Denning M.R. in Nippon Yusen Kaisha v. Karageorgis. ${ }^{10}$ The case concerned the failure of the defendant ship charterers to pay the agreed hire. The defendants had assets in London banks, and the plaintiff owners feared that these funds would be removed from the jurisdiction to prevent their being required to meet a judgement entitling them to the outstanding hire. They therefore sought an interlocutory injunction to restrain the defendants removing their assets from the jurisdiction. Donaldson J. refused the grant of such an injunction, but the Court of Appeal held that an order should be made. Lord Denning M.R., with whom Browne and Geoffery Lane L.JJ. agreed, noted that it had not been the practice of English courts to restrain the disposal of a defendant's assets in advance of a judgement, but held that this "practice"should be revised. He considered that the court possessed the jurisdiction to award an injunction in cases where there was a strong

\footnotetext{
${ }^{6}$ See: Devonshire, "The implications of third parties holding assets subject to a Mareva injunction" [1996] L.M.C.L.Q. 268; United Mizrahi Bank Ltd. v. Doherty [1998] 2 All E.R. 230.

${ }^{7}$ Usually the assets of the defendant will comprise money held by a bank. However the assets affected by a Mareva injunction may include chattels: Allen v. Jambo Holdings Ltd. [1980] 1 W.L.R. 1252; CBS United Kingdom Ltd. v. Lambert [1983] Ch. 37.

${ }^{8}$ (1890) 45 Ch.D. 1.

${ }^{9}$ Ibid at p. 14.

${ }^{10}$ [1975] 1 W.L.R. 1093.
} 


\section{EQUITY'S MANHATTAN PROJECT}

prima facie case that the hire was owing under section 45 of the Supreme Court of Judicature (Consolidation) Act 1925, which provided that the court could grant an injunction in all cases in which it appears to the court to be just or convenient so to do. ${ }^{11}$ The alleged jurisdiction to grant such an injunction was more fully explained in Mareva Compania Naviera S.A. v. International Bulkcarriers S.A., which similarly concerned unpaid hire due under a charterparty, and from which the Mareva injunction takes its name. ${ }^{12}$ Lord Denning considered that section 45 granted the court a wide ranging jurisdiction to grant an injunction whenever a plaintiff is seeking to protect a legal or equitable right, citing in support the judgement of his Victorian predecessor Sir George Jessel M.R. in Beddow v. Beddow who had stated that he enjoyed "unlimited power to grant an injunction in any case where it would be right or just to do so."13 Lord Denning considered that a creditor who has the prima facie right to have a debt paid enjoyed a sufficient legal right to raise the jurisdiction of the court to protect it by way of an injunction, even though he has not formally established his right by actually obtaining judgement for it. He thus concluded that where:

"it appears that the debt is due and owing - and there is a danger that the debtor may dispose of his assets so as to defeat it before judgement - the Court has jurisdiction in a proper case to grant an interlocutory judgement so as to prevent him disposing of those assets."14

Despite the obvious practical advantages of such a jurisdiction to restrain potential defendants from disposing of their assets and leaving a plaintiff with no effective remedy, the purported basis of it was spurious. ${ }^{15}$ Lister v. Stubbs ${ }^{16}$ was not the only preceding authority to deny the existence of any such jurisdiction. ${ }^{11}$ Technically the Court of Appeal was

\footnotetext{
"In Rasu Maritima S.A. v. Pertamina [1978] Q.B. 644 he subsequently drew support for the development of the Mareva jurisdiction from local customs in the City of London in the eighteenth century allowing the "foreign attachment" of assets. However it is now clear that the Mareva injunction is not a form of attachment, since it operates in personam and does not entitle the claimant to any proprietary interest in the assets affected: Mercedes-Benz A.G. v. Leiduck [1995] 3 All E.R. 929 at 939 per Lord Mustill.

12 [1975] 2 Lloyd's Rep. 509

13 (1878) 9 Ch.D. 89.

${ }_{15}^{14}$ Supra n.12 at p.510.

15 See: Meagher, Gummow and Lehane, Equity Doctrines \& Remedies, (3rd ed.,Sydney, Butterworths, 1992) at pp.607-609.

${ }^{16}$ Supra n.8.

${ }^{17}$ See: Robinson v. Pickering (1881) 16 Ch. D. 660; Newton v. Newton (1885) 11 P.D. 11;

Burmester v. Burmester [1913] P. 76; Scott v. Scott [1951] P. 193.
} 
bound by precedent. ${ }^{18}$ The fundamental objection to the award of such an injunction was the absence of any legal or equitable right on the part of the defendant protected by it. ${ }^{19}$ The plaintiff may have enjoyed a potential or putative right, but such a right did not crystallise until judgement was awarded in his favour. Roskill L.J. alluded to this difficulty in Mareva Compania Naviera S.A. v. International Bulkcarriers $S . A .^{20}$ when he indicated that Lister $v$. Stubbs ${ }^{21}$ could be distinguished on the grounds that the owners enjoyed a legal or equitable right under the terms of the charter, which provided that they should "have a lien upon all cargoes...for any amounts due." However he noted that the full extent and nature of that right "has long been a controversial matter which may have to be resolved." This reliance on the tenuous existence of such a lien justifying injunctive protection implies that the award of the injunction was otherwise novel, ${ }^{22}$ and not founded upon the existence of any other legal or equitable right which warranted protection.

The award of what quickly became known as "Mareva" injunctions was thus an example of spontaneous judicial creativity ex nihilo rather than of gradual legal development. A combination of the limited consideration of earlier authorities and the dubious interpretation of a statutory provision ${ }^{23}$ which can only be described as a "sleight of hand" enabled Lord Denning to assert the jurisdiction of equity to restrain a defendant parting with his assets before judgement is awarded against him. In Siskina (Cargo Owners) v. Distos Compania Naviera S.A. Lord Hailsham suggested that some of the arguments supporting the Mareva jurisdiction were "specious." ${ }^{24}$ It has been commented that in inventing this Mareva

${ }^{18}$ Mills v. Northern Railway of Buenos Ayres Co. (1870) L.R. 5 Ch. App. 621 at 628, per Lord Hatherley L.C. In Rasu Maritima S.A. v. Pertamina supra n.11. Lord Denning sought to differentiate Lister v. Stubbs supra n. 8. on the grounds that it did only applied to defendants who were outside of the jurisdiction. In the light of subsequent developments it is clear that this differentiation will not stand: Mercedes-Benz A.G. v. Leiduck supra n.11 at p. 939 per Lord Mustill.

${ }^{19}$ North London Railway Co. v. Great Northern Railway Co. (1883) 11 Q.B.D. 30; Thorne v. British Broadcasting Corporation [1967] 1 W.L.R. 1104.

${ }^{20}$ Supra $\mathrm{n} .12$ at pp.511-512.

${ }^{21}$ Supra n.8.

${ }^{22}$ Mercedes-Benz A.G. v. Leiduck supra n.11 at p.940 per Lord Mustill.

${ }^{23}$ In Mercedes-Benz A.G. v. Leiduck ibid Lord Mustill considered that the argument that the language of s.45 of the Supreme Court of Judicature (Consolidation) Act 1925 was sufficiently wide to found the jurisdiction to grant a Mareva injunction was inconsistent with the interpretation of that provision by the House of Lords in Siskina (Cargo Owners) v. Distos Compania Naviera S.A. [1979] A.C. 210, which had approved the judgement of Cotton L.J. in North London Railway Co. v. Great Northern Railway Co. supra n.19.

${ }^{24}$ [1979] A.C. 210 at 261. 


\section{EQUITY'S MANHATTAN PROJECT}

injunction the Court of Appeal was "nakedly exercising legislative power and usurping the functions of Parliament."25

The dubious authenticity of the jurisdiction to award a Mareva injunction must, however, be balanced against the practical imperatives that led the Court of Appeal to countenance such an invention. In Mareva Compania Naviera S.A. v. International Bulkcarriers S.A. the Court of Appeal stressed the overriding danger that the owners might not recover the hire owed if money held within the jurisdiction, and therefore readily available to meet any subsequent judgement debt, was removed. ${ }^{26}$ Roskill L.J. indicated that in the circumstances such removal would cause the plaintiffs to suffer a "grave injustice" which it would be wrong to tolerate. $^{27}$

\section{LEGITIMATION OF THE MAREVA INJUNCTION}

Despite the dubious origins of the Mareva injunction it quickly became a popular weapon in commercial litigation. ${ }^{28}$ Its validity was challenged before the Court of Appeal in Rasu Martina S.A. v. Pertamina, ${ }^{29}$ but Mareva Compania Naviera S.A. v. International Bulkcarriers $S . A .{ }^{30}$ was followed. In Siskina (Cargo Owners) v. Distos Compania Naviera S.A. the correctness of the jurisdiction was not raised as an issue before the House of Lords, and its legitimacy was not therefore determined. ${ }^{31}$ However Parliament effectively assumed ${ }^{32}$ the legitimacy of the Mareva jurisdiction by the enactment of section 37(1) of the Supreme Court Act 1981, which is the lineal successor of section 45 of the Supreme Court of Judicature (Consolidation) Act 1925. Whilst section 37(1) repeated the general jurisdiction of the court to grant an injunction "in all cases in which it appears to the court to be just and convenient to do so" subsection (3) expressly extended the infant Mareva jurisdiction by providing that:

"The power of the High Court under subsection (1) to grant an interlocutory injunction restraining a party to any proceedings from removing from the jurisdiction of the High Court, or otherwise dealing with, assets located

\footnotetext{
${ }^{25}$ Meagher, Gummow and Lehane, Equity Doctrines \& Remedies, supra n.15 at p.608.

${ }^{26}$ Supra n.12 at pp.511-512.

${ }^{27} \mathrm{Ibid}$ at p. 511 .

${ }^{28}$ See Siskina (Cargo Owners) v. Distos Compania Naviera S.A supra n.24 at pp.215-216 per Kerr J.

${ }^{29}$ Supra n.11.

${ }^{30}$ Supra n.12 at pp.511-512.

${ }^{31}$ Supra n.24.

${ }^{32}$ Mercedes-Benz A.G. v. Leiduck supra n.11 at p.938 per Lord Mustill.
} 


\title{
DENNING LAW JOURNAL
}

within that jurisdiction shall be exercisable in cases where that party is, as well as in cases where he is not, domiciled, resident or present within that jurisdiction."

Orthodoxy now regards this section as providing the jurisdictional basis of the Mareva injunction. ${ }^{33}$ Thus without any express acceptance by the House of Lords, or by Parliament, the Mareva injunction was accorded legitimate status. ${ }^{34}$ However as it is unlike other interlocutory injunctions the Mareva jurisdiction has been regarded as sui generis. ${ }^{35}$

\section{EXTENSION OF THE MAREVA JURISDICTION}

Once the Mareva injunction had been brought into existence the scope of its potential application was gradually enlarged. Initially it was thought to be confined to circumstances where the defendant was abroad, held assets within the jurisdiction which might be removed from it, and in respect of proceedings which would be brought within the jurisdiction. However, as Millett L.J. summarised in Credit Suisee Fides Trust v. Cuoghi:

\begin{abstract}
"it was progressively extended, in 1979 to English defendants, in 1982 by restraining defendants from dissipating their assets within the jurisdiction, and finally in 1990 by restraining defendants from dealing with their assets both inside and outside the jurisdiction.",36
\end{abstract}

\section{(a) Jurisdiction to grant a Mareva injunction against a defendant resident} within the jurisdiction

The early cases in which the Mareva jurisdiction emerged concerned unpaid ship hire. As Kerr J. had explained in Siskina (Cargo Owners) v. Distos Compania Naviera S.A. the practical reasons for the evolution of the jurisdiction were the depressed state of the freight market, the difficulty owners faced in arresting their ships as a means of enforcing their claim against the cargo, and the fact that the ships were managed from London, had been fixed on the Baltic exchange and that the charterparties contained a London arbitration clause. ${ }^{37}$ Given these circumstances the jurisdiction developed in a context where the assets

\footnotetext{
${ }^{33}$ Derby \& Co. Ltd. v. Weldon (No.s 3 \& 4) [1990] Ch. 65 at 76, per Lord Donaldson M.R..

${ }^{34}$ South Carolina Insurance Co. v. Assurantie Maatschappij "De Zeven Provincien" N.V. [1987] A.C. 24 at 39-40, per Lord Brandon; Mercedes-Benz A.G. v. Leiduck supra n.11 at p.938 per Lord Nicholls.

${ }^{35}$ Mercedes-Benz A.G. v. Leiduck supra n.11 at p.940 per Lord Mustill.

${ }^{36}$ [1997] 3 All E.R. 724 at 727.

${ }^{37}$ Supra n.24 at pp.215-216.
} 


\section{EQUITY'S MANHATTAN PROJECT}

sought to be impounded were within the jurisdiction but the defendant was abroad. $^{38}$ In Siskina (Cargo Owners) v. Distos Compania Naviera S.A. the Court of Appeal assumed, but did not decide, that the Mareva jurisdiction was confined to such cases and was not exercisable where the defendant was not abroad. ${ }^{39}$ However this limitation, if it in fact existed, ${ }^{40}$ was expressly removed by Parliament in section 37(3) of the Supreme Court Act 1981, which was cited above and provides that a Mareva injunction is available where a party "is...domiciled, resident or present within that jurisdiction."

(b) Jurisdiction to grant a Mareva injunction where there is a danger that the defendant will dispose of assets within the jurisdiction In the early cases it was also thought that a Mareva injunction was only available where it was felt that a defendant might remove his assets from the jurisdiction, but that there was no jurisdiction to make an order which would restrain a defendant from disposing of his assets within the jurisdiction. In Prince Abdul Rahman bin Turki al Sudairy v. Abu-Taha Lord Denning M.R. expressed his opinion that a Mareva injunction should be available if there was a danger that a defendant would dispose of his assets within the jurisdiction. ${ }^{41}$ Despite doubts as to the validity of his comments, ${ }^{42}$ which were strictly obiter, this proposition was later accepted, thus widening the scope of circumstances in which a plaintiff could obtain injunctive relief. ${ }^{43}$

\section{(c) Jurisdiction to grant a Mareva injunction preventing the dissipation of} assets held abroad

If Parliament extended the scope of the Mareva jurisdiction by section 37(3) of the Supreme Court Act 1981 so as to encompass a defendant who was present within the jurisdiction, the courts further extended its scope so as to enable the court to order a defendant not to dispose of assets which

\footnotetext{
${ }^{38}$ As was noted above, this was the very grounds upon which Lister v. Stubbs supra n. 8 had been distinguished, thus justifying the existence of the Mareva jurisdiction.

${ }^{39}$ Supra n.24 at p.229 per Lord Denning M.R.

${ }^{40}$ In Chartered Bank v. Daklouche [1980] 1 W.L.R. 107 it had been held that a Mareva injunction could be granted irrespective of whether the defendant was resident abroad or inside the jurisdiction.

${ }^{41}$ [1980] 1 W.L.R. 1268.

42 Faith Panton Property Plan Ltd. v. Hodgetts [1981] 1 W.L.R. 927; A.J. Bekhor \& Co. Ltd. v. Bilton [1981] Q.B. 923.

${ }^{43} Z$ Ltd. v. A-Z and AA-LL [1982] Q.B. 558; Ninemia Maritime Corporation v. Trave Schiffahrtsgesellschaft M.B.H. und Co. K.G. [1983] 1 W.L.R. 1412; CBS United Kingdom Ltd. v. Lambert supra n.7.
} 
were held outside of the jurisdiction. ${ }^{44}$ In Derby \& Co. Ltd. v. Weldon $(\text { No.s } 3 \& 4)^{45}$ the Court of Appeal concluded that the court possessed the jurisdiction to grant Mareva injunctions against foreign companies ${ }^{46}$ with no assets in the United Kingdom. All three members of the Court of Appeal stressed the evolving nature of the Mareva jurisdiction, and their right to develop it so as to meet changing commercial needs. Lord Donaldson M.R. emphasised that the practice of the commercial courts must adapt to take account of "rapidly growing commercial and financial sophistication" so that they meet "the current wiles of those defendants who are prepared to devote as much energy to making themselves immune to the courts' orders as to resisting the making of such orders on the merits of their case." ${ }^{, 47}$ Neil L.J. stated that the relatively recent emergence of the Mareva jurisdiction militated against concluding that it had become "ossified" and incapable of further evolution to meet changing circumstances. ${ }^{48}$ He thus held that it was time to:
"state unequivocally that in an appropriate case the court has power to grant an interlocutory injunction even on a world wide basis against any person who is properly so before the court, so as to prevent that person by the transfer of his property frustrating a future judgement of the court. $^{\text {"49 }}$

This extension in the potential scope of Mareva injunction was possible because the order operates in personam and not against the assets impounded. ${ }^{50}$ Initially the courts held that such world-wide injunctions should only be granted in "exceptional circumstances." More recently the Court of Appeal has further extended the jurisdiction by holding that a plaintiff seeking a world-wide Mareva injunction need only demonstrate that it would be expedient to grant such an order. ${ }^{52}$

\footnotetext{
${ }^{44}$ Ashianti v. Kashi [1987] Q.B. 888; Babanaft Intemational Co. S.A. v. Bassatne [1990] Ch. 13; Republic of Haiti v. Duvalier [1990] Q.B. 202; Derby v. Weldon (No. 1) [1990] Ch. 48.

${ }^{45}$ Supra n.33.

${ }^{46}$ One Panamanian and the other Luxembourg.

${ }^{47}$ Supra n.33 at p.77.

${ }^{48}$ Ibid at p.92.

${ }^{49}$ Ibid at p.93.

${ }^{50}$ See Derby v. Weldon (No. 6) [1990] 1 W.L.R. 1139 at 1149 per Dillon L.J..

${ }^{51}$ Derby \& Co. v. Weldon (No.1) supra n.44 at p.55 per May L.J.; Re BCCI S.A. (No. 9) [1994] 3 All E.R. 764 at 787, per Rattee J.

${ }^{52}$ Credit Suisee Fides Trust v. Cuoghi supra n.36.
} 


\section{EQUITY'S MANHATTAN PROJECT}

(d) Jurisdiction to grant a Mareva Injunction in aid of proceedings in a foreign court

In Siskina (Cargo Owners) v. Distos Compania Naviera S.A..$^{53}$ the House of Lords held that the court did not possess the jurisdiction to order a Mareva injunction against a foreign plaintiff with assets within the jurisdiction where the English court had no jurisdiction to pursue any action against the defendant and any action would only be able to be pursued abroad. ${ }^{54}$ In so doing they reversed the decision of the majority of the Court of Appeal, where Lord Denning had argued for a bold judicial extension of the right to grant an injunction. The House of Lords held that such an extension would require legislation. Lord Diplock remarked that it was "not for the Court of Appeal or for your Lordships to exercise these legislative functions, however tempting this may be,",55 and Lord Hailsham criticised Lord Denning for pre-empting Parliament and thus usurping the function of the legislature. ${ }^{56}$ Apart from his perceived constitutional impropriety, Lord Denning's attempted pre-emption of Parliament was to be vindicated by section 25 of the Civil Jurisdiction and Judgments Act 1982, which empowered the court to grant an injunction in respect of proceedings brought anywhere in the world. ${ }^{57}$ As Millett L.J. remarked in Credit Suisee Fides Trust v. Cuoghi:

"the position has now been reached...that the High Court has power to grant interim relief in aid of substantive proceedings elsewhere of whatever kind and wherever taking place., 58

\footnotetext{
${ }^{53}$ Supra n.24.

${ }^{54}$ In the circumstances an action could not be brought in England but could be brought in Italy.

${ }^{55}$ Supra n.24 at p.260.

${ }^{56}$ Ibid at p.262.

${ }^{57}$ Initially the jurisdiction under $\mathrm{s} .25$ was confined to European countries which were contracting parties to the Brussels and Lugano Conventions, but by virtue of the Civil Jurisdiction and Judgements Act 1982 (Interim Relief) Order 1997, S.I. 1997/302 the jurisdiction was extended to non-convention countries. For the position at common law before this extension of the scope of s.25 see: $X$ y. $Y$ [1990] 1 Q.B. 220; Mercedes-Benz A.G. v. Leiduck supra n.11; (1996) 112 L.Q.R. 8 (L. Collins); [1996] C.L.J. 12 (N. H. Andrews); (1996) 112 L.Q.R. 397 (P. St J. Smart); Credit Suisse Fides Trust v. Cuoghi supra n.36 at p.733 per Lord Bingham C.J. See also: Capper, "The Trans-Jurisidictional Effects of Mareva Injunctions" (1996) 15 C.J.Q. 211 ; Devonshire, "The implications of third parties holding assets subject to a Mareva injunction" supra n.6.

${ }^{58}$ Supra n.36 at p.724 at 728 . See also: Capper, ibid.
} 


\section{DENNING LAW JOURNAL}

(e) Jurisdiction to grant a world-wide Mareva Injunction in aid of proceedings in a foreign court

Since section 25 of the Civil Jurisdiction and Judgments Act 1982 extended the power of the court so as to entitle it to grant Mareva injunctions in respect of foreign proceedings the question inevitably arose whether the English courts possessed the jurisdiction to grant a worldwide Mareva injunction against the assets of defendant in aid of proceedings in a foreign jurisdiction. In Rosseel N.V. v. Oriental Commercial and Shipping (UK) Ltd. the Court of Appeal considered that such a world-wide Mareva injunction should only be granted in very exceptional circumstances, and that ordinarily the court should only act to support another jurisdiction to the extent of its own territorial jurisdiction. ${ }^{59}$ This restriction was simply a matter of practice rather than jurisdiction, and Lord Donaldson M.R. stressed that the court enjoyed the jurisdiction to grant such an order under section $25(1),{ }^{60}$ whilst section 25(2) expressly conferred upon it the right to refuse relief. This selfimposed limitation on the willingness of the court to grant a world-wide Mareva injunction in support of foreign proceedings was more recently reaffirmed by the Court of Appeal in S. \& T. Bautrading v. Nordling where Saville L.J. held that the decision in Rosseel N.V. was binding and that nothing in the intervening years had occurred to justify departing from it. ${ }^{61}$

In contrast in Credit Suisee Fides Trust v. Cuoghi a differently constituted Court of Appeal held that a world-wide Mareva injunction in support of foreign proceedings should be granted unless it is "inexpedient" to grant such an order as distinct from a merely domestic order, thus eliminating any unnecessary gloss on the language of section 25(2) which states that the court may refuse relief if the subject matter of the proceedings in question "makes it inexpedient for the court to grant it." Millett L.J. considered that the refusal of the Court of Appeal to grant an injunction in Rosseel N.V. was "surprising," especially since the defendants in that case were resident in England, even though the proceedings in question were brought in New York. ${ }^{63}$ Whilst the Court of Appeal emphasised the need to exercise caution in the grant of such injunctions so as to not to make orders conflicting with those of the court in which the proceedings will be heard, thus leading to "jurisdictional conflict, confusion or disharmony, ${ }^{, 64}$ the decision does seem to indicate

\footnotetext{
${ }^{59}$ [1990] 3 All E.R. 545

${ }^{60}$ The jurisdiction was exercised in Republic of Haiti v. Duvalier supra n.44.

${ }^{61}$ [1997] 3 All E.R. 718

${ }^{62}$ Supra $\mathrm{n} .36$ at p.727.

${ }^{63} \mathrm{Ibid}$ at p.731.

${ }^{64}$ Ibid at p.735 per Lord Bingham C.J.
} 
that a more liberal practice will be adopted in respect of the grant of interim relief where proceedings are brought outside of the jurisdiction, especially if the defendant is resident within the jurisdiction, as was the case in both Rosseel and Credit Suisee Fides Trust.

The mere fact that the English court possesses the jurisdiction to grant a Mareva injunction in aid of proceedings in a foreign court does not necessarily mean that such an injunction will be enforceable outside of the jurisdiction. Although injunctions granting interim relief constitute judgements within article 25 of the Brussels Convention, they will be unenforceable in contracting states if they were granted ex parte, since they will fall within the exemption of article $27(2){ }^{65}$

\section{(f) Jurisdiction to grant a Mareva injunction against a sovereign state}

Finally, it should be noted that the jurisdiction to grant a Mareva injunction extends to encompass an order against a foreign state if the right to sovereign immunity under the Sovereign Immunity Act 1978 has been waived. The right to immunity extends expressly to a central bank or other monetary authority. ${ }^{66}$ Thus in Camdex v. Bank of Zambia (No.2) the Court of Appeal held that the court possessed the jurisdiction to grant a Mareva injunction against assets of the Zambian Central Bank which were within the jurisdiction because it had expressly and irrevocably waived its right to plead sovereign immunity in the agreement that it had entered with the plaintiff. ${ }^{67}$

\section{(g) Safeguards to preventing oppressive exercise of the Mareva jurisdiction}

The Mareva injunction has evolved to become a formidable procedural weapon, and is usually obtained via an ex parte application. It has the potential to restrict a defendant's ability to deal with his property, whether within or without the jurisdiction, until a plaintiff's case has been resolved. In order to prevent abuse the courts have circumscribed and qualified their willingness to grant such injunctions with safeguards intended to protect the defendant from unjust and inappropriate coercion. An injunction will not be granted unless the plaintiff is able to demonstrate a good arguable case on the merits, ${ }^{68}$ thus exceeding the threshold ordinarily required for the grant of an interlocutory injunction. ${ }^{69}$ Where a contract is involved an injunction will only be granted if the

\footnotetext{
${ }^{65}$ De Cavel v. De Cavel (No. 1) [1979] E.C.R. 1055; Denilauler v. Couchet Freres [1980] E.C.R. 1553; EMI Records Ltd. v. Modern Music [1992] 1 Q.B. 115.

${ }^{66} \mathrm{~S} .13(3)$.

${ }^{67}$ [1997] 1 All E.R. 728.

${ }^{68}$ Nimenia supra n.43; Aiglon Ltd. v. Gau Shan Ltd. [1993] Lloyd's Rep. 167.

${ }^{69}$ American Cyanamid Co. v. Ethicon Ltd. [1975] A.C. 396.
} 
contract has been breached or the defendant has threatened to breach. ${ }^{70}$ The plaintiff is required to make full and frank disclosure of all matters in his knowledge ${ }^{71}$ and give grounds for believing that defendant will dissipate or remove his assets. ${ }^{72}$ The plaintiff will also be required to give an undertaking in damages to recompense the defendant if his claim subsequently proves to have been unjustified, ${ }^{73}$ although it remains a matter of discretion for the court whether to require the plaintiff to pay damages if the defendant suffers loss as a consequence of the injunction. ${ }^{74}$ Where a world-wide Mareva injunction is granted the plaintiff will be required to give an undertaking not to seek to enforce the injunction in any country other than England and Wales, ${ }^{75}$ and it may be appropriate to require an undertaking not to start any fresh proceedings in foreign courts arising out of the same subject matter. These limitations are intended to prevent the oppression of the defendant by exposure to a multiplicity of proceedings. A defendant will also be entitled to draw on funds frozen by a Mareva injunction to meet his legitimate expenses, including the reasonable legal costs of defending the subsequent action. ${ }^{76}$

\section{THE CREATION OF THE MAREVA INJUNCTION AS A PARADIGM FOR THE CONTINUING CREATIVITY OF EQUITY}

It has been seen how, over a twenty-year period, a jurisdiction has emerged to award an injunction of an entirely novel nature. The authenticity of this jurisdiction is now beyond question, ${ }^{77}$ having been assumed by Parliament, accepted by the House of Lords, adopted in other common law jurisdictions, ${ }^{78}$ and most significantly having come to serve a crucial role in the practice of commercial litigation. It is inconceivable that the jurisdiction will be overturned on the grounds that it is a creature of heresy. Whilst the eventual involvement of the legislature in the legitimation of the Mareva injunction should not be overlooked, in reality

\footnotetext{
${ }^{70}$ The Veracruz [1992] 1 Lloyd's Rep. 353; The P [1992] 1 Lloyd's Rep. 470; Zucker v. Tyndall Holdings plc [1992] 1 W.L.R. 1127.

${ }^{71}$ Third Chandris Corp. v. Unimarine S.A. [1979] Q.B. 645.

${ }^{72}$ Ketchum v. Group Public Relations [1997] 4 All E.R. 374.

${ }^{73}$ Third Chandris Corp. v. Unimarine S.A. supra n.71.

${ }^{74}$ Balkanbank v. Taher [1994] 4 All E.R. 239.

${ }^{75}$ Derby \& Co. v. Weldon (No.1) supra n.44; Practice Direction (Mareva Injunctions and Anton Piller Orders) [1994] 1 W.L.R. 1233; Practice Direction (Mareva Injunctions and Anton Piller Orders) [1996] 1 W.L.R. 1552.

${ }^{76}$ PCW (Undertaking Agencies) Ltd. v. Dixon [1983] 2 All E.R. 697; Law Society v. Shanks (1987) 131 S.J. 1626; Fitzgerald v. Williams [1996] 2 All E.R. 171.

${ }_{77}$ Mercedes-Benz A.G. v. Leiduck supra n.11 at p.944 per Lord Nicholls.

${ }^{78}$ Hunt v. B.P. Exploration Company (Libya) Ltd. [1980] 1 N.Z.L.R. 104 (New Zealand); Jackson v. Sterling Industries Ltd. (1987) 162 C.L.R. 332 (Australia).
} 


\section{EQUITY'S MANHATTAN PROJECT}

the jurisdiction was the product of judicial creativity and an assertion of the ability of equity to create a remedy adequate to meet the needs of the moment. Equity has always maintained the need for principle and practice to evolve rather than to remain static, ${ }^{79}$ which includes the ability to devise new rights and remedies. At times there has been a marked reluctance to countenance any enduring creative power of equity, on the grounds that this would usurp the proper function of Parliament, ${ }^{80}$ lead to radically unacceptable uncertainty, ${ }^{81}$ or that any development should be confined to the extension and development of existing principle. ${ }^{82}$ As has been noted, all of these objections have been raised against the Mareva injunction, and yet it has endured. They are not insuperable barriers to the creation of new rights and remedies.

Lord Denning fathered the Mareva jurisdiction. His approach was characterised by a boldness which bordered on the brazen. In Siskina (Cargo Owners) v. Distos S.A. ${ }^{83}$ he urged judges not to be timorous in the face of an obvious need for reform to meet injustice, modifying a hymn of William Cowper to this effect:

\section{"Ye fearful [judges], fresh courage take, The clouds ye so much dread, Are big with [justice], and shall break In blessings on your head. ${ }^{, 84}$}

He considered that this ethos would enable the judiciary to "find a good way to law reform," exercising the court's inherent jurisdiction to lay down the practice and procedure of the courts. The House of Lords rejected such an approach, regarding any judicial extension of the rules governing the jurisdiction to serve a Mareva injunction as an unacceptable appropriation of the powers of Parliament. In contrast Lord Denning was unwilling to stand by and allow the defendants to dissipate their assets only for Parliament to "shut the stable door after the steed has been stolen." His prescience of the need for change was only ultimately vindicated by the extension of the scope of section 25 of the Civil Jurisdiction and Judgments Act 1982 by the Civil Jurisdiction and

\footnotetext{
${ }^{79}$ See Re Hallett's Estate (1880) 13 Ch. D. 696 at 710, per Jessel M.R.,

${ }^{80}$ Western Fish Products v. Penwith District Council [1981] 2 All E.R. 204; Westdeutsche Landesbank Girocentrale v. Islington L.B.C. [1996] 2 All E.R. 961.

${ }^{81}$ Cowcher v. Cowcher [1972] 1 W.L.R 425 at 430 per Bagnall J.; Allen v. Snyder [1977] 2

N.S.W.L.R. 685; Westdeutsche Landesbank Girocentrale v. Islington L.B.C ibid at p.992 per Lord Browne-Wilkinson.

${ }^{82}$ Re Diplock [1948] Ch.465; Cowcher v. Cowcher ibid.

${ }^{83}$ Supra n.24.

${ }^{84} \mathrm{Ibid}$ at 236.
} 


\section{DENNING LAW JOURNAL}

Judgements Act 1982 (Interim Relief) Order $1997 .{ }^{85}$ The failure to act boldly, as Lord Denning had suggested, bedevilled the law of jurisdiction for almost twenty-years, and in Mercedes-Benz A.G. v. Leiduck ${ }^{86}$ Lord Nicholls considered, in his dissenting opinion, that the House of Lords had taken a "wrong turning in the Siskina." This time-lag between the recognition of the need for change, and the response of the legislature accomplishing it, demonstrates the problems associated with a reliance on Parliament as the sole agent of legal reform. The pressures on parliamentary time imposed by a government's legislative programme inevitably consign sensible proposals for reform to the back of the queue, as witnessed by the many Law Commission reports which have not been implemented. Moreover, judges feel constrained to preserve the status quo even where there is no convincing argument in its favour. In Prudential Assurance Co. Ltd. v. London Residuary Body the House of Lords felt unable to offer any coherent rationale for the historic common law requirement that a lease must be for a term certain, thus requiring a fixed maximum duration, but nevertheless considered that it would be inappropriate to overturn such a long standing rule. ${ }^{87}$ Such judicial reticence will only ensure that the law remains shackled by the chains of history, ${ }^{88}$ even where they have no contemporary relevance.

At the end of this century, one hundred years after Lord Denning's birth, there are significant aspects of the law of equity which are ripe for change if the judiciary are willing to take the initiative. There is near unanimity amongst theorists that the present distinctions between the common law and equitable rules of tracing, especially concerning their respective ability to follow property though a mixed fund, are unjustifiable and should be abolished in the interests of justice. ${ }^{89}$ The House of Lords has raised the prospect of the introduction of a restitutionary remedial constructive trust, ${ }^{90}$ which is in practice uncannily similar to Lord Denning's proposed "new model" constructive trust. It has been argued that the established principles of "knowing receipt," whereby a stranger to a trust is liable to account as a constructive trustee for the value of trust property he received other than as a bona fide purchaser, should be replaced by a strict liability to make restitution on the grounds of mere receipt alone, without the need to demonstrate any degree of fault, actual

\footnotetext{
${ }^{85}$ S.I. $1997 / 302$

${ }^{86}$ Supra n.11 at p.951.

${ }^{87}$ [1992] 3 All E.R. 504

88 United Australia v. Barclays' Bank Ltd. [1941] A.C. 1 at 29 per Lord Atkin.

${ }^{89}$ See for example, the comments of Millett L.J. in Jones (F.C.) \& Sons v. Jones [1996] 4 All E.R.721 at 729 .

${ }^{90}$ Westdeutsche Bank v. Islington L.B.C. supra n. 80 .
} 


\section{EQUITY'S MANHATTAN PROJECT}

or constructive. ${ }^{91}$ If such developments are to occur they will require judicial boldness equivalent to that demonstrated by Lord Denning demonstrated in the creation of the Mareva jurisdiction, abandoning the shackles of historic precedents and the fear of constitutional impropriety in the interests of justice and the demands of the moment. It remains to be seen whether the judges will take such steps. The history of the Mareva jurisdiction demonstrates that radical innovation is possible. The subsequent legitimation and consolidation of the Mareva jurisdiction demonstrates that each individual reform will have to stand the test of time before it is accepted as orthodox, having been judged on its merits through usage, thus proving whether it achieves practical justice without sacrificing a legitimate concern for legal certainty and stability.

\footnotetext{
${ }^{91}$ See for example: Harpum, "The Basis of Equitable Liability"in Birks (ed.) The Frontiers of Liability Vol.1 (Oxford University Press, 1994); A. J. Oakley, "The Liberalising Nature of Remedies for Breach of Trust" in Oakley (ed.), Trends in Contemporary Trust Law (Clarendon Press, 1996); at pp.247-251; Jill Martin, "Recipient Liability after Westdeutsche" [1998] Conv. 13; Lord Nicholls, "Knowing Receipt: The Need for a New Landmark," in Cornish, Nolan, O'Sullivan \& Virgo, Restitution Past, Present \& Future: essays in honour of Gareth Jones (Hart Publishing, 1998), Chapter 16.
} 